\title{
Polish scientists form free union
}

Polish scientists and university teachers have been quick to set up an independent trade union.

The Gdansk accords, signed on 31 August between Vice Premier Mieczyslaw Jagielski for the Polish Government and Mr Lech Walesa for the Joint Strike Committee of the Baltic littoral, guarantees to all Polish workers the right if they so choose to set up "free trade unions independent of Party and employees".

On 8 September, the new "Independent Union of Scientific, Technical and Educational Workers', (Zwiazek Pracownikow Nauki, Technikii Oswiaty ZPNTO) was established, and two days later it held its first delegate meeting, with 286 delegates (one for every 50 members) representing scientific and academic institutions throughout Poland.

During the labour unrest of the past two months, Polish scientists had kept a fairly low profile, although in at least two institutes of the Academy of Sciences Experimental Biology, and Hydrology and Meteorology - meetings of support had been held to urge an aggreement with the Joint Strike Committee.

The establishment of the ZPNTO is far more than an act of solidarity; the new chairman of ZPNTO, Zdzislaw Bibrowski, a researcher into energy problems at the Institute of Fundamental Problems of Technical Science of the Polish Acedemy of Sciences, considers that the Gdansk accords represent a new chance for Polish academic life to regain its autonomy, and freedom of research. "This is a problem of vital concern to all scientists," he said. Although ZPNTO hopes to act as a conventional trade union, defending the dayto-day interests of its members, its leaders see the issue of academic autonomy as allimportant. If this is granted, they imply, many other problems will solve themselves. Already there are demands from the universities that rectors should be appointed by secret ballot and that senior appointments should be made on the basis of academic criteria only.

Such demands do not come only from ZPNTO. Last week the Party-linked Socialist Union of Polish Students published its own set of postulates, demanding greater autonomy for higher educational institutes, restoration of open discussion and a "moral revival" of the academic community. The governing board of the existing Union of Polish Teachers has adopted a resolution pledging itself to full democratization, independence and self-government; it seems in effect to have disestablished itself from the Central Council of Trade Unions. Addressing the start-of-session conference of university rectors last week, Janusz Gorski, Minister of Higher Education and Science, said that the postulates on higher

education put forward by the various academic establishments were now being studied, while Politburo member Andrzej Werblan urged public discussion on the issue of self-government in higher education as a basis for reforms. Even the Scientific Secretary of the Academy of Sciences, Dr Jan Kaczmarek, told a meeting of directors of research institutes that the academy will have to make a number of internal changes and redefine its role in the scientific community.

For those who have chosen the option of an independent trade union, however, the main practical problem at the moment is to get the new union registered as soon as the new legislation is through. Inevitably, there is considerable organizational work to be done, and ZPNTO is not attempting to rush things. The committee was elected by secret ballot at the delegate meeting and will hold office for only three months during the period of consolidation.

This committee, incidentally, represents a wide range of disciplines: two other physicists, Andrzej Ziabicki and Zbigniew Peradzynski, also from the Institute of Fundamental Problems of Technical Science, Tadeusz Klopotowski from the Institute of Biophysics and Biochemistry,

\section{DNA recombination forces resignation}

\section{Washington}

Dr Samuel I.T. Kennedy last weekend resigned his post at the department of biology at the University of California, San Diego, in the wake of a critical report from the institution's biosafety committee. Dr Kennedy has been in hot water for the past several weeks, since it first became known that he had carried out cloning experiments with the Semliki Forest virus (SFV) at a time when cloning of the virus was prohibited under the recombinant DNA guidelines promulgated by the National Institutes of Health (NIH) (see Nature, 14 August).

Dr Kennedy has from the outset said that his work with Semliki Forest virus was accidental, and that he had been intending to clone fragments of the genome of another arbovirus, Sindbis virus. At one stage it had been suggested that the two kinds of viruses were confused when a package of vials containing various virus specimens was damaged during air transport from the United Kingdom.

The report prepared for NIH by the university's institutional biosafety committee now says that it does not accept Dr Kennedy's description of the experiments that were carried out, and suggests that the violation of the guidelines may have been deliberate.

This possibility, which has been strongly denied by $\mathrm{Dr}$ Kennedy, has led the committee to continue its ban on further
Krystyna Starczewska from the Institute of Philosophy and Sociology and Piotr Sasinski from the Institute of Literary Research. The only member of the committee not employed in one of the Academy's institutes is Viktor Kulerski, a school-master. The interim committee is largely Warsaw based, but Dr Bibrowski stressed that ZPNTO membership represents the academic community of the whole of Poland, and one of the main items discussed at the delegate meeting was the need to facilitate enrolment of academic workers outside the capital.

However, not all the Polish academic community is entirely happy about the foundation of ZPNTO. Last week's delegate meeting was held in the building of NOT (Naczelna Organizacja Techniczna - Chief Technical Organization) in Warsaw. When, however, the delegates and other supporters arrived (some 500 people in all), the NOT officials were unwilling to admit them. Only after lengthy negotiations were they allowed to go in, and even then only on condition that the chairman of NOT read a formal statement that NOT was acting merely as proprietor of the hall and accepted no responsibility for what might transpire. Vera Rich

cloning experiments in his laboratory. It argues that agreements between research workers and biosafety committees must be based on mutual trust; and that in the absence of such trust "permission for cloning should not be granted".

The report contains two separate sections, one presenting a chronology of events as determined by the committee, the other the shronology as described by $\mathrm{Dr}$ Kennedy. Both descriptions agree on many points, in particular that subsequent laboratory tests revealed that cloning of SFV DNA had indeed occurred when it was prohibited by NIH guidelines (a prohibition that has since been lifted).

But there are significant differences in some of the details of the experiments and their timing. According to Dr Kennedy, defective interfering (DI) virus particles were prepared from stocks of Sindbis virus early in 1979 and subsequently used to generate further Sindbis DI particles. RNA prepared from the particles was cloned in a strain of $E$. coli in December 1979, and the DNA isolated from this clone was successfully used in January 1980 to transform mouse L cells.

The committee gives a slightly different version of events. It claims that it was a Semliki Forest virus preparation enriched in DI particles that was used in the summer of 1979 and that the DNA was used to infect cells in August and subsequently in January of this year. According to the 